\title{
Digital Anti-Corruption Typology for Public Service Delivery
}

\author{
Fredrick Mutungi \\ Department of Computer Science \\ Faculty of Computing and Informatics \\ Mbarara University of Science and Technology, \\ Uganda \\ Department of Computer Studies \\ Faculty of Science \& Education \\ Busitema University, Uganda
}

\author{
Annabella Habinka Dorothy Basaza-Ejiri \\ Makerere University \\ College of Computing and Information Sciences \\ School of Computing and Informatics \\ Department of Information Technology \\ Kampala, Uganda
}

\author{
Rehema Baguma \\ Makerere University \\ College of Computing and Information Sciences \\ School of Computing and Informatics \\ Department of Information Systems \\ Kampala, Uganda
}

\author{
Tomasz Janowski \\ Department of Applied Informatics in Management \\ Gdańsk University of Technology \\ Poland Department for E-Governance and \\ Administration \\ Danube University Krems, Austria
}

\begin{abstract}
Digital anti-corruption refers to a family of digital technology tools that are used to fight corruption. Many such tools have not performed well in practice due to their non-alignment with forms of corruption they are supposed to fight against and persistence of corruption-enabling conditions. The aim of this paper is to contribute to filling this gap by offering a typology of digital anti-corruption in public service delivery that can be used to decide what digital measures should be applied to fight against specific forms of corruption or address specific corruption-enabling conditions. The typology also highlights that digital technology can both assist in corrupt practices e.g. theft, falsification and destruction of digital personal records and aid the fight against corruption e.g. mobile channels to report incidents of corruption, automated audits of transaction records to uncover fraudulent payments, or service automation to replace discretionary decision making by public officials with rule-based automated decision-making. The typology is grounded in research and policy literature and validated using real-life examples from East Africa.
\end{abstract}

\section{General Terms}

Corruption, Typology, Mobile technology

\section{Keywords}

Corruption, Public Services, Anti-corruption, Digital anticorruption measures, Anti-Corruption Typology.

\section{INTRODUCTION}

The delivery of public services in an effective and efficient manner, at the right quantity and quality, at the right place and time is the primary responsibility of any government [1]. However, this responsibility has not been fulfilled by many governments due to corruption.

Transparency International defines corruption as the abuse of public power for private gain [2]. Corruption can be classified as grand or petty, depending on the amounts of money lost [2]. Grand corruption is the abuse of high-level power that benefits the few at the expense of the many, and causes serious and widespread harm to individuals and society and pervades the highest levels of government [3]. Petty corruption is corruption at the implementation end of public administration, involving the payment of comparatively small amounts of money to facilitate official transactions [2]. In addition to grand and petty classifications [4] identified two more classifications which cover corruption typologies based on developed and developing nations. This paper extends literature by identifying classifications of corruption in public service delivery and the corresponding corruption-enabling conditions in delivery of public health services.

Digital technology has been at the forefront of the fight against administrative corruption in general and corruption in public service delivery in particular, with many African countries such as Kenya, Ghana, Malawi, Nigeria, Senegal and Uganda embarking on digital anti-corruption initiatives [5][6][7]. However, many digital tools have not been performing well in practice due to their non-alignment with forms of corruption they are supposed to fight [8] and persistence of corruption-enabling conditions [9].

The aim of this paper is to contribute to filling this gap by offering a typology of digital anti-corruption in public service delivery that can be used to decide what measures should be applied to fight against specific forms of corruption or address corruption-enabling conditions. The rest of the paper is structured as follows. Section 2 gives the background of the study. Section 3 describes the research methodology. Section 4 presents theoretical framework. Section 5 describes case studies for corruption in public service delivery. Section 6 presents the digital anti-corruption typology. Section 7 discusses the findings and section 8 offers some conclusions.

\section{BACKGROUND}

A number of tools, strategies and methods have been used to fight corruption in public service delivery in different contexts, but there is a lot of evidence that corruption is still a big problem in many, especially developing countries [2]. For 
example, corruption in public service delivery in the three East African countries - Uganda, Kenya and Tanzania remains endemic regardless of the anti-corruption laws and institutions put in place [10]. Globally, the three countries rank among the most corrupt countries in the world. In 2015, Uganda and Kenya shared position 139 out 168 countries and Tanzania was ranked at the position 119 out of 175 countries [11].

Proponents of using Information and Communication Technology (ICTs) in enhancing service delivery consider ICTs to have a big potential in eliminating conditions that favor corruption [6], [12]-[14] . Consequently, a lot of efforts have been invested in developing ICT-based anti-corruption measures in different countries as a means of minimizing corruption by increasing access to information [15]. Although there has been considerable success, there have also been several failed attempts to use ICTs in monitoring delivery of public services [16]-[18]. Examples of failed attempts include the Computer-aided Administration of Registration Department (CARD), a registration system in the state of Andhra Pradesh [19]; Pancha Tantra online in Karnataka, India [14]; and "Not In My Country" (NIMC) project, in Ugandan universities [20].

Technology access is one of the main barriers of using the mainstream computer-based ICTs in monitoring the delivery of public services [21]. However, given substantial growth in use of digital and mobile technologies [21], a number of researchers discern the potential of such technologies for monitoring the delivery of public services and promoting good governance, transparency and accountability [22] [23][24][25][26][27][22]-[28]. As a way of harnessing this potential, a number of countries have embarked on digital anti-corruption initiatives. Such initiatives are part of the larger digital government effort in transforming public administration and its relationships with citizens through digital technology to empower citizens to create public value by themselves, and to achieve sustainable development outcomes in the process[29].

Digital anti-corruption refers to a family of digital tools that are used to fight corruption. An example is the Online Procedure Enhancement (OPEN) system for civil applications of Seoul Metropolitan Government [30] and Seoul eProcurement System (GePS)[30].In Uganda, commonly used digital tools and systems are mobile Tracking (mTrac), AKVO flow, Bespoke and Open Data Kit (ODK)[31]. However, many such tools also have not performed well in practice due to their non-alignment with the forms of corruption they are supposed to fight against and persistence of corruption-enabling conditions [32], [33].

As a way of improving performance of such tools in fighting corruption,[6] provided a typology of technology-based corruption management which promotes government of the people. This paper contributes to [6] work by offering a typology of digital anti-corruption measures in public service delivery that can be used to decide what digital measures should be applied to fight against specific forms of corruption or address specific corruption-enabling conditions. This paper is an extension of the earlier presented conference paper in which a digital anti-corruption typology was proposed by [31].

\section{METHODOLOGY}

A typology for digital anti-corruption includes classification of different types of corruption in public service delivery and their enabling conditions, measures used to fight corruption and weaken its enabling conditions, and digital technologies used to support such measures.
To develop such a typology, the study adopted a scoping review methods, which aims at rapidly mapping the key concepts underpinning a research area and the main sources and types of evidence available [34]. The review mainly focused on corruption and anti-corruption measures in the delivery of public services of the three East African countries - Uganda, Kenya and Tanzania.

According to the five stages of the scoping review methods, the adopted methodology entails:

1. Identifying the research question: The research question is: What is the typology for digital anticorruption that can be used to improve the anticorruption performance in public service delivery?

2. Identifying relevant studies: The search for relevant studies was conducted in electronic research databases like Scopus, Academic Premier and ERIC, policy and legal publications by relevant organizations, and reference lists. The search applied combinations of the terms like "corruption", "anti-corruption", "measures", "public service", etc. mostly published within the last 10 years.

3. Study Selection: The references were imported into the Mendeley tool for easy referencing. Priority was given to the articles with abstracts referencing forms of corruption, conditions that enable corruption, anti-corruption measures, and digital anti-corruption technologies used to fight corruption. The literature search resulted in 895 abstracts. Out of these, only 557 relevant full-text papers were accessed due to limitations of time and cost. Again, 99 were excluded for not being directly related to any of the search criteria; forms of corruption, conditions that enable corruption, anti-corruption measures and digital anti-corruption technologies. Finally, 458 papers were included. Of these 458 papers, 199 were papers that described forms of corruption, 26 described conditions that enable corruption and 58 for general anti-corruption measures, 8 methodology papers while 167 were digital anticorruption technologies papers.

4. Charting the Data: To keep within the desired scope, the following attributes were used for identified studies: authors, publication years, study locations, study types and methodologies, problems addressed, technologies used, and the purpose of the interventions.

5. Collating, summarizing and reporting the results: The findings were organized according to: different forms of corruption, conditions that enable corruption, anti-corruption measures, and the use of digital technologies to support such measures. Across such themes, real-life examples were used from the health sector in the Eastern Africa region.

Although corruption affects all public service sectors, the health sector is particularly vulnerable mainly due to uncertainty about service demands and information asymmetry among actors [35]. Thus, the public health service sector was judged as a fitting case study for examining the use of digital anti-corruption measures against rampant corruption in the delivery of public health services in East Africa.

\section{THEORETICAL FRAMEWORK}

This section provides a framework for classifying mobile 
technologies used against corruption in delivery of public services. The framework outlines different corruption theories that explain different corruption enabling conditions and how anti-corruption mechanisms can address these conditions. These theories include: Principal-agent theory and collective action theory [36][37].

\section{Principal-Agent Theory}

The principal-agent theory highlights the role of individuals' calculations about whether or not to engage in or oppose corruption; the influence of transparency, monitoring, and sanctions on those calculations; and the technical challenges of monitoring and sanctioning corrupt behavior. This conceptualization considers citizens as the principal and government officials, political leaders, and bureaucrats alike as agents acting on their behalf [36][38]. The agents have political discretion and monopoly over the distribution of resources, hence a big potential for corruption [36][38]. Thus, strategies to fight corruption should focus on decreasing power discretion of individual government officials and on giving both their superiors and citizens means to monitor their work [36][38].

\section{Collective action theory}

This theory highlights the relevance to individuals' decisions of group dynamics, including trust in others and the behavior of others. That is, when a group of individuals perceive corruption as normal and believes everyone else is involved, they may be less willing to abstain from it or to take the first step in fighting it [38]. Strategies to fight this type of corruption aim to increase community engagement -public awareness raising and working with civil society to build trust in society through the potential benefits of mobile technologies [38].

These two theories informed the development a typology of digital anti-corruption typology in public service delivery.

\section{CORRUPTION IN PUBLIC SERVICE DELIVERY}

In this section, a set of categories to develop a typology of digital anti-corruption is presented in form of: forms of corruption in public service delivery in Uganda, Kenya and Tanzania (Section 5.1); corruption-enabling conditions in society, economy and politics (Section 5.2); measures against different forms of corruption (Section 5.3); and measures addressing corruption- enabling conditions (Section 5.4). Each section introduces relevant forms, measures or technologies of corruption, and illustrates them with case examples from any of the East African country.

\subsection{Forms of Corruption}

The analysis of the relevant literature revealed that corruption in the delivery of public services can be classified as grand or petty, depending on the amounts of money lost [11]. Grand corruption is the abuse of high-level power that benefits the few at the expense of the many, and causes serious and widespread harm to individuals and society [39]. Petty corruption, on the other hand, is corruption in public administration, at the politics' implementation end, and involves the payment of comparatively small amounts of money to facilitate official transactions [40]. Whether grand or petty, corruption can also be classified as political, administrative or systemic [41]. Political corruption involves lawmakers [40]. Administrative corruption includes the use of bribery and favoritism to allow individual businesses to lower their taxes, escape regulations, or win low-level procurement contracts. Systemic corruption is where bribery is routine in dealings between the public and individuals. This type of corruption affects service delivery through all levels of society [40].

Corruption has also been classified according to the perpetrators' behavior. In this classification, corruption can entail nepotism, favoritism, bribery, extortion, intimidation, abuse of office, fraud, embezzlement, insider trading, conflict of interest, illegal contributions or staff absenteeism [4] Nepotism implies sharing of the state resources, appointments and promotions with one's family members and relatives, not based on the merits [42]. Related to nepotism is favoritism, preferential treatment by an entrusted office holder on the basis of family or friendship relationship, or ethnic, party or religious affiliation [40]. Bribery is the act of offering and receiving extra legal means to influence the performance of a constituted responsibility [4]. Extortion involves coercive means to extract financial benefits while discharging one's official duty [40]. Abuse of power refers to a situation where one's authority is unscrupulously applied to obtained preferential benefits [43]. Yet another form of corruption, among others, is the ghost worker, where the names of nonexisting workers are added to the payroll to obtain undue salaries or subventions [42]

Cases of grand corruption include the estimated loss of more than USD 300 million by Government of Uganda due to corruption between 2011 and 2013 [44]. The funds were lost through the creation of "ghost" projects and "ghost" public servants, diversion of foreign aid and local government funds to private bank accounts, bidding and selling government assets at lower costs, diverting logistics for public servants' welfare, and poorly monitored revenue sources and programs [45]. Petty corruption is mostly in the form of bribes which clients pay to public officers. In Uganda, for example, patients at public health facilities pay for drugs and other free services [46]. Based on the above, Table 1 summarizes forms of corruption in public service delivery.

Table 1: Forms of corruption in public service delivery

\begin{tabular}{|l|l|l|}
\hline Category & Form & References \\
\hline Grand & Bribery & {$[40]$} \\
\cline { 2 - 2 } & Extortion & {$[11]$} \\
\cline { 2 - 2 } & Embezzlement & {$[4][42]$} \\
\cline { 2 - 2 } & Fraud & {$[47]$} \\
\cline { 2 - 2 } & Political & \\
\hline consideration & {$[41][45]$} \\
\cline { 2 - 2 } & Kickbacks & {$[48]$} \\
\cline { 2 - 2 } & Collusion & {$[49]$} \\
\hline Bureaucratic/Petty & Theft & {$[40]$} \\
\cline { 2 - 2 } & Extortion & {$[40]$} \\
\cline { 2 - 2 } & Embezzlement & {$[45]$} \\
\cline { 2 - 2 } & Intimidation & {$[47]$} \\
\cline { 2 - 2 } & Fraud & {$[10]$} \\
\cline { 2 - 2 } & Absenteeism & \\
\hline & & Informal payments \\
\cline { 2 - 2 } & & {$[40]$} \\
\hline
\end{tabular}




\begin{tabular}{|l|l|l|}
\hline \multirow{5}{*}{} & Nepotism & {$[4]$} \\
\cline { 2 - 2 } & Favoritism & {$[43]$} \\
\cline { 2 - 2 } & Insider trading \\
\cline { 2 - 2 } & Conflict of interest \\
\hline Systemic & $\begin{array}{l}\text { Can take on any } \\
\text { form of corruption } \\
\text { like [40] } \\
\text { Extortion, Bribery, } \\
\text { Embezzlement }\end{array}$ & \\
\hline
\end{tabular}

\subsection{Corruption-Enabling Conditions}

Studies have established a mixture of situations, attitudes and processes that create an enabling environment or facilitate corruption in public service delivery [9]. These conditions include:

Poor institutional design, in terms of political structure, legal structure, rule of law and culture amplify discretionary power of public officials thereby increasing opportunities for corrupt behavior [41].

Organizational factors like lack of moral criteria in promotions are other enablers [51]. Bad economic conditions that create a fertile ground for corruption [52].

Low levels of development which reduces education and literacy and limits the ability of citizens to serve as watchdogs over public officials' activities [53].

Low public service wages [54]. Cultural environments that condone corruption. Some cultures defend and sometimes admire corrupt practices [51]. Personal ethics and greed that lead to an unfettered desire for money or power [55].

Information barriers and asymmetry between monopoly services and service recipients-citizens [56]. Lack of transparency and accountability also create opportunities for public officials to abuse their office for private gain [55]. Based on the above, Table 2 summarizes conditions that enable corruption in public service delivery.

Table 2: Conditions that favor corruption in public service delivery

\begin{tabular}{|c|c|}
\hline Conditions & References \\
\hline $\begin{array}{c}\text { Lack of transparency and } \\
\text { accountability }\end{array}$ & {$[45][57][40]$} \\
\hline Low public service wages & {$[58][59]$} \\
\hline Discretionary power & {$[41][57][60]$} \\
\hline Institutional factors & \\
\hline Limited citizen voice & \\
\hline Organizational factors & \\
\hline Cultural conditions & \\
\hline Personal ethics & \\
\hline Personal greed & \\
\hline Monopoly power & \\
\hline Low economic development & \\
\hline Information asymmetry & \\
\hline
\end{tabular}

\subsection{Anti-Corruption Measures}

Viewing corruption through a principal-agent lens, corruption is 'solvable' with policies that alter the degree to which principals are able to monitor and sanction their agents and the level of discretion given to agents and their individual incentive calculations [61]. Consequently, anti-corruption measures should focus on reducing the discretion of civil servants, increasing monitoring mechanisms, promoting transparency in government, supporting anti-corruption civil society groups to serve as watchdogs, and strengthening sanctions on those who engage in corruption, so as to better align the incentives of potential 'agents' with those of their respective 'principals [36][60]. These measures can be grouped into two categories, namely direct measures that aim at specific manifestations of corruption and indirect measures that aim at removing or weakening conditions that favor corruption [62].

\section{Direct Measures Against Corruption}

The direct measures aim at fighting exact manifestations of corruption. This category includes financial audits to detect fraud, embezzlement, theft or absenteeism; anti-corruption commissions to detect political corruption; or asset recovery for theft, embezzlement or fraud [61]. Other measures are strengthening internal control systems, asset recovery, and monitoring and enforcement [9].

Examples of direct measures against corruption in Uganda include the development of the National Anti-Corruption Strategy (NACS) in 2008, Anti-Corruption Act, Public Procurement and Disposal of public Assets Act 2003, and the anti-corruption court [63]. Ugandan Government has also put in place a number of institutions such as the Inspectorate of Government, Directorate of Ethics and Integrity, The Auditor General, Directorate of Public Prosecution, The Public Accounts Committee of Parliament, the Medicines Monitoring Unit in the Presidents' office, and Anti-Corruption Court for prosecution of corrupt officials. However, the effectiveness of these institutions remains severely limited [46]. Table 3 summarizes anti-corruption measures with the forms of corruption they are meant to address.

Table 3: Direct anti-corruption measures and corresponding forms of corruption

\begin{tabular}{|c|c|c|c|}
\hline $\begin{array}{c}\text { Anticorrupt } \\
\text { ion } \\
\text { Measures }\end{array}$ & $\begin{array}{l}\text { Forms of } \\
\text { corruption }\end{array}$ & References & $\begin{array}{c}\text { Comment } \\
\text { s }\end{array}$ \\
\hline \multirow{4}{*}{$\begin{array}{c}\text { Anti- } \\
\text { corruption } \\
\text { commissions }\end{array}$} & Bribery & \multirow{9}{*}{$\begin{array}{c}{[50][63][64]} \\
{[48][65]} \\
{[66]}\end{array}$} & \multirow{4}{*}{$\begin{array}{l}\text { Mandated } \\
\text { to combat } \\
\text { and } \\
\text { prevent } \\
\text { any form } \\
\text { of } \\
\text { corruption. }\end{array}$} \\
\hline & $\begin{array}{c}\text { Embezzleme } \\
\text { nt }\end{array}$ & & \\
\hline & $\begin{array}{c}\text { Political } \\
\text { corruption }\end{array}$ & & \\
\hline & Collusion & & \\
\hline \multirow{4}{*}{$\begin{array}{c}\text { Prosecution } \\
\text { of corrupt } \\
\text { officials }\end{array}$} & Bribery & & \multirow{4}{*}{$\begin{array}{l}\text { Works for } \\
\text { both grand } \\
\text { and petty } \\
\text { corruption. }\end{array}$} \\
\hline & $\begin{array}{c}\text { Embezzleme } \\
\mathrm{nt}\end{array}$ & & \\
\hline & Theft & & \\
\hline & political & & \\
\hline $\begin{array}{l}\text { Code of } \\
\text { conduct for } \\
\text { public } \\
\text { officials }\end{array}$ & $\begin{array}{c}\text { Bureaucratic } \\
\text { corruption }\end{array}$ & & $\begin{array}{l}\text { It is } \\
\text { mainly for } \\
\text { bureaucrati } \\
\mathrm{c} \text { forms of } \\
\text { corruption. }\end{array}$ \\
\hline
\end{tabular}




\begin{tabular}{|c|c|c|c|}
\hline \multirow{3}{*}{$\begin{array}{l}\text { Assets } \\
\text { Recovery }\end{array}$} & Theft & & \multirow{3}{*}{$\begin{array}{l}\text { Meant to } \\
\text { recover } \\
\text { lost } \\
\text { property or } \\
\text { funds. }\end{array}$} \\
\hline & $\begin{array}{l}\text { Embezzleme } \\
\mathrm{nt}\end{array}$ & & \\
\hline & Fraud & & \\
\hline Monitoring & $\begin{array}{l}\text { Most forms } \\
\text { of corruption }\end{array}$ & [63] & $\begin{array}{l}\text { Meant for } \\
\text { all forms } \\
\text { of corrupt } \\
\text { behavior. }\end{array}$ \\
\hline
\end{tabular}

\subsection{Measures Addressing Corruption- Enabling Conditions}

Indirect measures against corruption in public service delivery aim at weakening conditions that favor corruption such as those examined in Section 5.2 [67]. The indirect measures include: monitoring of transactions to uncover opaque decision making, civil service reform to address low public service wages, stringent code of conduct or addressing low ethics issues, behavior and transaction monitoring, staff rotation, breaking the culture of secrecy, cutting the red tape, and sensitization of the public [68]. In Uganda, for example, indirect anti-corruption measures used include: regular National Integrity Surveys, public awareness programs, preparation and submission of corruption reports to the parliament, monitoring government projects and enforcing accountability [63]. The government of Uganda has also carried out a number of public service reforms to address graft in the public sector, for example decentralization of the civil servant payroll to eliminate "ghost workers" [63]. Table 4 shows the different conditions favoring corruption and the corresponding indirect measures to address the

Table 4: Indirect Anti-Corruption Measures

\begin{tabular}{|c|c|c|c|}
\hline $\begin{array}{l}\text { Anti- } \\
\text { Corruption } \\
\text { Measures }\end{array}$ & $\begin{array}{l}\text { Conditions } \\
\text { Favoring } \\
\text { Corruption }\end{array}$ & References & Comment \\
\hline Monitoring & $\begin{array}{l}\text { Lack of } \\
\text { transparency } \\
\text { and } \\
\text { accountability }\end{array}$ & [63] & $\begin{array}{l}\text { Reduces } \\
\text { both grand } \\
\text { and petty } \\
\text { corruption }\end{array}$ \\
\hline \multirow{2}{*}{$\begin{array}{l}\text { Introducing } \\
\text { civil service } \\
\text { reforms }\end{array}$} & $\begin{array}{l}\text { Low public } \\
\text { service wages }\end{array}$ & [54] [69] & \multirow{2}{*}{$\begin{array}{l}\text { Used } \\
\text { against } \\
\text { petty } \\
\text { corruption }\end{array}$} \\
\hline & Red tape & [63] & \\
\hline \multirow[t]{2}{*}{$\begin{array}{l}\text { Sensitizatio } \\
\mathrm{n} \text { of the } \\
\text { public }\end{array}$} & $\begin{array}{l}\text { Cultural } \\
\text { conditions }\end{array}$ & \multirow[t]{2}{*}{$\begin{array}{l}68][70] \\
{[10]}\end{array}$} & \multirow{2}{*}{$\begin{array}{l}\text { Changes } \\
\text { attitudes } \\
\text { and values } \\
\text { of society }\end{array}$} \\
\hline & $\begin{array}{l}\text { Information } \\
\text { barriers and } \\
\text { asymmetry }\end{array}$ & & \\
\hline $\begin{array}{l}\text { Stringent } \\
\text { code of } \\
\text { conduct }\end{array}$ & Personal ethics & [10] & $\begin{array}{l}\text { Applied to } \\
\text { both grand } \\
\text { and petty } \\
\text { corruption }\end{array}$ \\
\hline \multirow[t]{3}{*}{$\begin{array}{l}\text { Increasing } \\
\text { access to } \\
\text { information }\end{array}$} & $\begin{array}{l}\text { Lack of } \\
\text { transparency } \\
\text { and } \\
\text { accountability }\end{array}$ & \multirow[t]{3}{*}{$\begin{array}{l}{[63]} \\
{[71][72]}\end{array}$} & \multirow[t]{3}{*}{$\begin{array}{l}\text { Applied to } \\
\text { both grand } \\
\text { and petty } \\
\text { corruption }\end{array}$} \\
\hline & $\begin{array}{l}\text { Cultural } \\
\text { conditions }\end{array}$ & & \\
\hline & $\begin{array}{l}\text { Limited } \\
\text { citizen voice }\end{array}$ & & \\
\hline
\end{tabular}

\begin{tabular}{|c|c|c|c|}
\hline & $\begin{array}{l}\text { Information } \\
\text { barriers and } \\
\text { asymmetry }\end{array}$ & & \\
\hline \multirow[t]{8}{*}{$\begin{array}{l}\text { Engaging } \\
\text { service } \\
\text { beneficiaries }\end{array}$} & $\begin{array}{l}\text { Lack of } \\
\text { transparency } \\
\text { and } \\
\text { accountability }\end{array}$ & [73] & \multirow[t]{8}{*}{$\begin{array}{l}\text { Suitable for } \\
\text { petty } \\
\text { corruption }\end{array}$} \\
\hline & $\begin{array}{l}\text { Cultural } \\
\text { conditions }\end{array}$ & {$[74]$} & \\
\hline & $\begin{array}{l}\text { Limited } \\
\text { citizen voice }\end{array}$ & [55] & \\
\hline & $\begin{array}{l}\text { Information } \\
\text { barriers and } \\
\text { asymmetry }\end{array}$ & {$[56]$} & \\
\hline & Personal ethics & \multirow[t]{4}{*}[74]{} & \\
\hline & $\begin{array}{l}\text { Limited } \\
\text { citizen voice }\end{array}$ & & \\
\hline & $\begin{array}{l}\text { Discretionary } \\
\text { power }\end{array}$ & & \\
\hline & $\begin{array}{l}\text { Monopoly } \\
\text { power }\end{array}$ & & \\
\hline
\end{tabular}

\section{TYPOLOGY OF DIGITAL ANTI- CORRUPTION}

According to principal-agent and collective action theories presented earlier, technology is more likely to have a positive impact against corruption, if the necessary conditions within which corruption occurs are known and targeted by specific types of digital technologies. Hence, the need to align the different digital technologies capabilities with the different forms of corruption, conditions facilitating corruption and existing anti-corruption measures. The digital anti-corruption typology therefore, refers to different classifications of digital technologies according to how they are used directly or indirectly to fight corruption. The different types of technologies are meant to cater for different types of corruption, which are facilitated by different conditions illustrated in the previous sections on the country and sectoral levels. Each of the categories aims at the exact forms of corruption, at conditions that favor corruption, or at both. Common categories in the reviewed literature comprise: digital anti-corruption technologies used for gathering information, for data aggregation and visualization, for mobilizing the public to demand accountability and for automation and auditing to address fraud [75].

These categories are covered in subsequent sections 6.1 to 6.4 .

\subsection{Digital Anti-Corruption for Gathering Information}

Within this category, digital technology is used to gather data for enhancing upward transparency in public service delivery [6][75]. Information about service delivery performance such as stock outs, worker absenteeism, bribery, etc. can be collected. The commonly used technologies include SMS free 'Please Call Me' messages, Interactive Voice Response services, or ordinary telephone hotlines [6][75]. One such example is Kenya's integrated public complaints referral mechanism, a joint effort between five government agencies and one NGO to develop a more efficient process for handling citizen complaints regarding among others corruption [71], [76]. Other examples include "Not In My Country" project, a crowdsourcing platform used to record, report, and publicize corruption in Ugandan Universities [20], and IPaidABribe, Corruption Tracker and Hatari in Kenya which provide means for citizens to anonymously submit reports of bribery and 
irregularities in the public sector [21].

\subsection{Digital Anti-Corruption for Data Aggregation and Visualization}

This family of technologies is used to summarize, analyze and present information to the public for downward transparency. For example, analytics dashboards for summarizing and displaying data on government practices and crowdsourced data and interactive digital mapping of independent reports are under this classification [77]. The open source Ushahidi platform in Kenya which enables registered users to process reports and upload them to a digital map for online visualization is a typical example of an analytics dashboard used to summarize crowd sourced reports[77][75]. The platform gets its data through crowds. Crowds submit data via SMS, smartphone apps, email, twitter or online [75]. Other technologies include online data mapping tools or dashboards and digital analytics technologies such as the DHIS 2.0 software that enables processing of large amounts of data for easy visualization [75]. In Uganda, Ministry of Health uses DHIS 2.0 for data aggregation and presentation at the district level.

\subsection{Digital Anti-Corruption for Mobilization}

The highlighted technologies can be effective in fighting corruption in public service delivery institutions measures through increased transparency and accountability, provided citizens use them [67][45]. The technologies are heavily dependent on citizen participation and if not used, there is no content and value to fight corruption [56]. Hence, another category of digital anti-corruption technology identified from the literature is technologies for mobilization. This category is used for mobilizing citizens to take up new technologies, changing their attitudes about corruption, and generating political pressure for change. Use of blogging, SMS and social media in anti-corruption campaigns are typical examples. Other technologies used for mobilization against corruption are videos and interactive websites, and citizengovernment dialogue with SMS [75]. For example, in Tanzania, the Chanjo project used blogging, SMS and social media to mobilize citizens against corruption. The use of the Internet and social media enabled the project to reach 11,000 users in three months [75], [77].

\subsection{Digital Anti-Corruption for Automation}

In this category, digital technologies are mainly used to automate discretionary activities with potential for abuse among public officials [75], [77]. Automation helps eliminate the discretion of public officials, cuts out intermediaries, and reduces red tape and bureaucracy in public service delivery. In turn, this reduces opportunities for corruption and favoritism by public officials [56]. Examples include the use of GPS and biometrics to detect staff absenteeism, disbursing salaries with mobile banking, checking for counterfeit medicines via SMS, and using algorithms to detect fraudulent data [31]. For example, Kenyan Government introduced the use of digital cash registers to address the problem of staff stealing user fee revenue in government hospitals [31]. Blockchain is being explored as a digital anti-corruption tool. The technology stores copies of data in different servers in a decentralized, peer-to-peer network in different locations around the world [77]. This design supports a verifiable record which cannot be changed without changing subsequent blocks, hence reducing chances for fraud to pass undetected [77]. However, developing countries like the three East African countries still have a long way to go in implementing the blockchain technology because of the lack of infrastructure[78].

In relation to the identified conditions that favor corruption in table 2, mobile technology can mainly be used to reduce too much discretion, monopoly power, lack of transparency, lack of accountability, limited citizens' voice, and enforcement. The rest of the enabling conditions like low wages, personal greed, financial problems at home, and social pressures social norms, moral beliefs, attitudes and personality may not be reduced. Therefore, effective utilization of the proposed typology also depends on other social, economic, political, infrastructural and legal anti-corruption considerations.

It should also be noted that the main logic behind use of mobile technology to reduce/eliminate corruption is to improve supply and demand sides of information exchanges and limiting the scope of public official's discretion. However, this logic may not apply for some forms of grand corruption where politicians may even legislate for corruption. Thus, while we recognize that the use of technology to fight corruption is important, it should be noted that technology alone will never be sufficient to eliminate corruption. Table 5 below summarizes the different conditions that facilitate corruption and relevant digital measures to reduce/eliminate such conditions.

Table 5: Types of Digital Anti-Corruption Measures

\begin{tabular}{|c|c|c|}
\hline $\begin{array}{l}\text { Corruption- } \\
\text { enabling } \\
\text { conditions }\end{array}$ & $\begin{array}{l}\text { Digital } \\
\text { measure }\end{array}$ & Description \\
\hline $\begin{array}{l}\text { Lack of } \\
\text { transparency and } \\
\text { accountability }\end{array}$ & $\begin{array}{l}\text { Transparency } \\
\text { portals }\end{array}$ & $\begin{array}{l}\text { Platforms that offer } \\
\text { timely publication of } \\
\text { key government } \\
\text { documents online }\end{array}$ \\
\hline $\begin{array}{l}\text { Limited citizen } \\
\text { voice }\end{array}$ & SMS & \begin{tabular}{ll}
\multicolumn{2}{l}{ Citizen-government } \\
dialogue & through \\
SMS &
\end{tabular} \\
\hline \multirow[t]{4}{*}{$\begin{array}{l}\text { Information } \\
\text { barriers } \\
\text { information } \\
\text { asymmetry }\end{array}$} & $\begin{array}{l}\text { Crowd sourced } \\
\text { reporting }\end{array}$ & $\begin{array}{l}\text { Platforms that allow } \\
\text { large numbers of } \\
\text { citizens to report } \\
\begin{array}{l}\text { corruption } \\
\text { grievances }\end{array}\end{array}$ \\
\hline & $\begin{array}{l}\text { Social media } \\
\text { and blogging }\end{array}$ & $\begin{array}{lr}\text { Mobilizing } & \text { the } \\
\text { community } & \text { to report } \\
\text { incidents } & \text { of } \\
\text { corruption } & \end{array}$ \\
\hline & $\begin{array}{l}\text { Open data } \\
\text { portal }\end{array}$ & $\begin{array}{l}\text { Providing free access } \\
\text { to public data }\end{array}$ \\
\hline & $\begin{array}{l}\text { Internet } \\
\text { services }\end{array}$ & $\begin{array}{l}\text { Timely publication of } \\
\text { information }\end{array}$ \\
\hline $\begin{array}{l}\text { Discretionary } \\
\text { power }\end{array}$ & $\begin{array}{l}\text { Service } \\
\text { automation }\end{array}$ & $\begin{array}{l}\text { Automation replaces } \\
\text { discretionary decision }\end{array}$ \\
\hline Monopoly power & Online services & 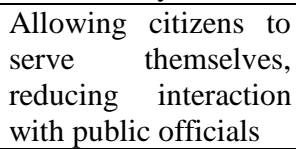 \\
\hline $\begin{array}{l}\text { Poor supervision } \\
\text { of services }\end{array}$ & $\begin{array}{ll}\text { GPS and } \\
\text { biometrics }\end{array}$ & $\begin{array}{l}\text { Fighting public } \\
\text { servant absenteeism }\end{array}$ \\
\hline \multirow[t]{2}{*}{$\begin{array}{l}\text { Lack of } \\
\text { transparency and } \\
\text { accountability }\end{array}$} & $\begin{array}{l}\text { Automated } \\
\text { audits of } \\
\text { transactions }\end{array}$ & $\begin{array}{l}\text { Removing } \\
\text { intermediaries }\end{array}$ \\
\hline & $\begin{array}{ll}\text { Use } & \text { of } \\
\text { algorithms } & \text { to } \\
\text { detect fraud } & \end{array}$ & $\begin{array}{l}\text { Used to create } \\
\text { auditable log of } \\
\text { transactions for easy } \\
\text { detection } \\
\text { fraudulent activities }\end{array}$ \\
\hline
\end{tabular}




\section{DISCUSSION}

The main research question of this study was "what is the typology for digital anti-corruption that can be used to improve the anti-corruption performance in public service delivery?" To answer this research question, the study used scoping review methods [79] to identify and classify mobile technologies used against corruption in public service delivery. The identified categories were: digital anticorruption technologies used for gathering information, data aggregation and visualization, mobilizing the public to demand accountability and for automation and auditing to address fraud [75]. These categories show the different ways in which digital technologies are used to fight corruption in delivery of public services. Basing on their functionalities as proposed by [80], the technologies were classified into a typology. The typology highlights that digital technology can both assist in corrupt practices e.g. theft, falsification and destruction of digital personal records much as it aid the fight against corruption. e.g. mobile channels to report incidents of corruption, automated audits of transaction records to uncover fraudulent payments, or service automation to replace discretionary decision making by public officials with rulebased automated decision-making. The typology is in agreement with principal-agent theory which states the strategies to fight corruption should focus on decreasing power discretion of individual government officials [36], [38] and the collective action theory which states that strategies to fight corruption should aim at increasing community engagement [38].

This typology can be used to decide what digital measures should be applied to fight against specific forms of corruption or address specific corruption-enabling conditions. The typology has implications for e-government implementation, in particular for the research area of digital anti-corruption. First, it was noted that many digital tools have not been performing well in practice due to their non-alignment with the forms of corruption and corruption-enabling conditions they are supposed to address. Governments can overcome this challenge and improve their anticorruption performance by acquiring digital anti-corruption tools for monitoring the delivery of public services or tailored tools to address specific forms of corruption. Secondary, some digital anti-corruption tools like crowdsourcing tools or whistleblowing platforms constitute a huge risk for their users, if not protected. Thus, relevant authorities must introduce strong security mechanism and laws to protect the users of such platforms. Thirdly, a number of digital anti-corruption tools have not realized their potential due to limited usage. One of the usage barriers is capacity gap, so relevant authorities should endeavor to train potential users while protecting their identity. Lastly, some digital anti-corruption tools have had limited impact because their availability is not known. Therefore, relevant authorities should sensitize members of the public about availability and security of such tools.

\section{CONCLUSIONS}

In this study, we examined the digital technology tools being used to support direct and indirect anti-corruption measures against administrative corruption in general and public service corruption in particular. After reviewing literature using scoping review methods, it was discovered that many of these digital anti-corruption tools have not been performing well in practice due to their non-alignment with the forms of corruption or with corruption-enabling conditions they are supposed to fight against.

This paper contributed to addressing this gap by offering a typology of digital anti-corruption in public service delivery that can be used to decide which measures should be applied to fight against specific forms of corruption or address specific corruption-enabling conditions. The typology is based on the review of relevant research and policy literature, on the cases of three East African countries - Uganda, Kenya and Tanzania. With this typology in place, guidance is provided on deploying digital anti-corruption tools or combinations of such tools to match specific corruption threats and conditions that enable and trigger such threats.

Although four categories of digital anti-corruption were identified as main tools used in monitoring delivery of public services, this study used only literature review as a method of data collection. It is therefore possible that there could be other forms of undocumented corruption or conditions that are not met with by these measures. Therefore, future researchers should consider extending this typology using other research methods and use it to check whether there are forms of corruption or conditions that are not met by the identified measures.

\section{REFERENCES}

[1] C. Egberi, A. E., \& Madumelu, "Corruption and Service Delivery in Local Government System in Nigeria: A Content Analysis," Int. J. Bus. Soc. Sci., vol. 5, no. 10, 2014.

[2] R. Parveen, Y. J. Amuda, and S. Hassan, "Effects of corruption on the human social economic development: A case study of India, Nigeria and Bangladesh," Int. J. Econ. Res., vol. 14, no. 20, pp. 373-388, 2017

[3] A. Bolanle, "Forensic Accounting As a Tool for Fighting Corruption and Terrorism: Case Study of Nigeria," Int. J. Soc. Sci. Econ. Res., vol. 2, no. 1, pp. 2210-2225, 2017 , [Online].

Available: http://ijsser.org/uploads/ijsser_02_137.pdf.

[4] N. Suleiman and Z. Othman, "Corruption Typology: A Review of Literature," Chinese Bus. Rev., vol. 16, no. 2, p. 102, 2017, doi: 10.17265/1537-1506/2017.02.004.

[5] M. Cummins and B. Huddleston, "Real time monitoring for the most vulnerable: UNICEF's experience in Uganda," IDS Bull., vol. 44, no. 2, pp. 57-68, 2013.

[6] E. Okewu and J. Okewu, "E-government, e-Governance and e-Administration: A Typology of Corruption Management Using ICTs," in European Conference on e-Government, 2015, pp. 203-212.

[7] I. Holeman, T. P. Cookson, and C. Pagliari, "Digital technology for health sector governance in low and middle income countries: A scoping review," J. Glob. Health, vol. 6, no. 2, 2016, doi: 10.7189/jogh.06.020408.

[8] J. Lemaire, "Scaling up mobile health: Elements necessary for the successful scale up of mHealth in developing countries." Geneva: Advanced Development for Africa, 2011.

[9] A. Mills, "Causes Of Corruption In Public Sector Institutions and Its Impact On Development: Turning What We Know Into What We Do," no. May, pp. 1-35, 2012.

[10] AfriMAP, Effectiveness of Anti-Corruption Agencies in East Africa. 2015.

[11] Transparency International, "Corruption Perceptions Index 2015,” 2015. doi: 978-3-943497-18-2. 
[12] S. Basu, "E- government and developing countries: an overview," Int. Rev. Law, Comput. Technol., vol. 18, no. 1, pp. 109-132, Mar. 2004, doi: $10.1080 / 13600860410001674779$.

[13] J. Gaventa and R. McGee, "The Impact of Transparency and Accountability Initiatives," Dev. Policy Rev., vol. 31, pp. s3-s28, Jul. 2013, doi: 10.1111/dpr.12017.

[14] S. Bhatnagar, "Public Service Delivery: Role of Information and Communication Technology in Improving Governance and Development Impact. Asian Development Bank.," 2014, [Online]. Available: http://www.adb.org/sites/default/files/publication/31238/ ewp-391.pdf.

[15] M. Lodge and L. Stirton, "Regulating in the Interest of the Citizen: Towards a Single Model of Regulatory Transparency?," Social and Economic Studies, vol. 50. Sir Arthur Lewis Institute of Social and Economic StudiesUniversity of the West Indies, pp. 103-137, 2001, doi: $10.2307 / 27865234$

[16] R. Heeks, "Most e-Government-for-Development Projects Fail How Can Risks be Reduced ?," 2003.

[17] R. Heeks and H. Mathisen, "Understanding success and failure of anti-corruption initiatives," Crime, Law Soc. Chang., vol. 58, no. 5, pp. 533-549, Dec. 2012, doi: 10.1007/s10611-011-9361-y.

[18] Haslinda Sutan Ahmad Nawi, A. A. Rahman, and O. Ibrahim, "Government's ICT project failure factors: A revisit," in 2011 International Conference on Research and Innovation in Information Systems, Nov. 2011, pp. 1-6, doi: 10.1109/ICRIIS.2011.6125738.

[19] A. Prakash and R. De', "Importance of development context in ICT4D projects," Inf. Technol. People, vol. 20, no. 3, pp. 262-281, Aug. 2007, doi: $10.1108 / 09593840710822868$.

[20] J. Hellström and B. Bocast, "Many 'likers' do not constitute a crowd: The case of Uganda's Not In My Country," in ICT for anti-corruption, democracy and education in East Africa, 2013.

[21] J. C. Bertot, P. T. Jaeger, and J. M. Grimes, "Using ICTs to create a culture of transparency: E-government and social media as openness and anti-corruption tools for societies," Gov. Inf. Q., vol. 27, no. 3, pp. 264-271, Jul. 2010, doi: 10.1016/J.GIQ.2010.03.001.

[22] R. McGee and R. Carlitz, "Learning Study on 'The Users' in Technology for Transparency and Accountability Initiatives: Assumptions and Realities," 2013.

[23] J. Hellström, "Who leads, who follows? Re-examining the party-electorate linkages on European integration," $J$. Eur. Public Policy, vol. 15, no. 8, pp. 1127-1144, Dec. 2008, doi: 10.1080/13501760802407649.

[24] J. Hellström and A. Karefelt, "Mobile participation? crowdsourcing during the 2011 uganda general elections," 2012.

[25] T. D. Susanto and R. Goodwin, "Factors Influencing Citizen Adoption of SMS-Based e-Government Services," Electron. J. e-Government, vol. 8, no. 1, pp. $55-70,2010$.

[26] H. Wasserman, "Mobile Phones, Popular Media, and
Everyday African Democracy: Transmissions and Transgressions," Pop. Commun., vol. 9, no. 2, pp. 146158, Apr. 2011, doi: 10.1080/15405702.2011.562097.

[27] A. A. Olorunnisola and B. L. Martin, "Influences of media on social movements: Problematizing hyperbolic inferences about impacts," Telemat. Informatics, vol. 30, no. 3, pp. 275-288, Aug. 2013, doi: 10.1016/J.TELE.2012.02.005.

[28] CIPESA, "How Ict Tools Are Promoting Citizen Participation in Uganda," 2012.

[29] T. Janowski, E. Estevez, and R. Baguma, "Platform governance for sustainable development: Reshaping citizen-administration relationships in the digital age," Gov. Inf. Q., no. August, pp. 1-16, 2018, doi: 10.1016/j.giq.2018.09.002

[30] M. S. S. J.-W. Iqbal and J.-W. Seo, "E-Governance as an anti corruption tool Korean cases," J. Korean Assoc. Reg. Inf. Soc. vol. 11(no. 2), 2008, Accessed: Feb. 03, 2019 [Online].

Available: https://www.kdevelopedia.org/Resources/governmentlaw/e-governance-as-anti-corruption-tool-05201506220138576.do?fldIds=TP_GOV\%7CTP_GOV _PA\#.XFbEE1VKhLs.

[31] T. Mutungi, F., Baguma, R., Janowski, "Towards digital anti-corruption typology for public service delivery," in ACM International Conference Proceeding Series, 2019, pp. 484-494, doi: 10.1145/3325112.3325266.

[32] A. Grönlund, Using ICT to combat corruption-tools, methods and result, no. 3. 2010.

[33] T. Davies and S. Fumega, "Mixed incentives: Adopting ICT innovations for," no. 4, pp. 1-24, 2014, [Online]. Available: http://www.cmi.no/publications/file/5172mixed-incentives.pdf.

[34] H. Arksey and L. O. Malley, "SCOPING STUDIES: TOWARDS A METHODOLOGICAL FRAMEWORK," pp. 19-32, 2005.

[35] T. Vian, "Review of corruption in the health sector: theory, methods and interventions," pp. 83-94, 2008, doi: 10.1093/heapol/czm048.

[36] A. Neupane, "UNIVERSITY OF SOUTHERN QUEENSLAND E-PROCUREMENT TECHNOLOGY TO REDUCE CORRUPTION IN PUBLIC PROCUREMENT," no. July, 2014.

[37] F. B. Osang, N. Abinwi, and C. Tsuma, "Reviewing Information Systems Usage and Performance Models," Int. J. Comput. Sci. Inf. Technol., vol. 6, no. 1, pp. 476484, 2015.

[38] N. Kossow, "Anti-Corruption and Integrity Programme Embracing Digitalisation: How to use ICT to strengthen Anti-Corruption Embracing Digitalisation: How to use ICT to strengthen Anti-Corruption," 2018.

[39] Transparency International, "Corruption Perceptions Index 2016,” 2016. doi: 10.1051/0004-6361:20021392.

[40] J. Andvig, O. Fjeldstad, and T. Søreide, "Research on Corruption: A Policy Oriented Survey," Int. Aff., no. December, pp. 1-144, 2000.

[41] S. Rose-Ackerman and B. J. Palifka, Corruption and Government. Cambridge: Cambridge University Press, 
2016

[42] O. B. Ijewereme, "Anatomy of Corruption in the Nigerian Public Sector," SAGE Open, vol. 5, no. 2, p. 215824401558118, Jun. 2015, doi: $10.1177 / 2158244015581188$.

[43] D. E. Agbiboa, "Protectors or Predators? The Embedded Problem of Police Corruption and Deviance in Nigeria," Adm. Soc., vol. 47, no. 3, pp. 244-281, Apr. 2015, doi: $10.1177 / 0095399713513142$.

[44] Human Rights Watch, "Letting the Big Fish Swim" Failures to Prosecute High-Level Corruption in Uganda. 2013.

[45] Å. Asiimwe, E.N., Wakabi, W. and Grönlund, "ICT for Anti-Corruption , Democracy and Education in East Africa ICT for Anti-Corruption , Democracy and Education in East Africa," no. 6. 2013.

[46] Inspectorate of Government, "Using the data tracking mechanism 2014,” 2014.

[47] K. R. Hope, Corruption and Governance in Africa. 2017.

[48] S. Lindner, "Tanzania: Overview of corruption and anticorruption," 2012. [Online]. Available: https://www.u4.no/publications/tanzania-overview-ofcorruption-and-anti-corruption.

[49] T. Vian, "Review of corruption in the health sector: theory, methods and interventions," Health Policy Plan., vol. 23, no. 2, pp. 83-94, Nov. 2008, doi: 10.1093/heapol/czm048.

[50] Inspectorate General, "Using the data tracking mechanism 2014,” 2014.

[51] D. Mele, "Corruption: 10 Possible Causes | Business Ethics."

https://blog.iese.edu/ethics/2014/11/06/corruption-10possible-causes/ (accessed Feb. 03, 2019).

[52] V. Tanzi, "Corruption Around the World: Causes, Consequences, Scope and Cures," 1998.

[53] R. (Eds. ). (2006). T. role of parliament in curbing corruption. W. B. P. Stapenhurst, R., Johnston, N., \& Pelizzo, Curbing corruption. 2006.

[54] CIPE, "Combating Corruption: A Private Sector Approach," 2011. [Online]. Available: http://www.worldbank.org/en/topic/governance/brief/anti -corruption.

[55] S. Rose-Ackerman and B. J. Palifka, Corruption and Government. Cambridge: Cambridge University Press, 2016.

[56] K. Gopakumar, "Increasing information access to improve political accountability and participation: mapping future actions in Asia Pacific," 2001.

[57] K. R. Hope Sr., "Tackling the corruption epidemic in \{Kenya\}: \{Toward a policy of more effective control," J. Soc. Polit. Econ. Stud., vol. 38, no. 3, pp. 287-316, 2013, [Online]. Available: http://www.scopus.com/inward/record.url?eid=2-s2.084884473260\&partnerID $=40 \& \mathrm{md} 5=1235 \mathrm{f} 24114 \mathrm{e} 783 \mathrm{fc} 3$ b3d74585a4083af.

[58] CIPE, "Combating Corruption: A Private Sector Approach,” 2011.
[59] P. N. Nyingi, "Kenya Wins a Gold Medal for Corruption," Int. J. Innov. Res. Inf. Secur., vol. 04, no. 03, pp. 1-10, 2017.

[60] CETA, "Corruption and Democratic Practices in Tanzania," Civ. Educ. Teach. Assoc., vol. 9, 2011.

[61] H. Marquette and C. Peiffer, "Collective Action and Systemic Corruption," ECPR Jt. Sess. Work. Univ. Warsaw, no. April, pp. 1-28, 2015.

[62] S. B. ed. Ebb, Public Sector Reform: What Works and Why? An IEG Evaluation of World Bank Support. 2008.

[63] M. Martini, "Uganda overview of corruption and anti corruption. U4 Expert Answer. TI.," vol. U4, no. April, 2013.

[64] World Bank, Global Economic Prospects 2010. 2008.

[65] P. N. Nyingi, "Kenya Wins a Gold Medal for Corruption," vol. 04, no. 03, pp. 1-10, 2017.

[66] D. Ringold, A. Holla, M. Koziol, and S. Srinivasan, "Citizens and service delivery: assessing the use of social accountability approaches in human development sectors," 2011.

[67] U. Office of the President, "National Strategy To Fight Corruption and Rebuild Ethics and Integrity in Uganda," 2008.

[68] A. Mills, "Causes of corruption in public sector institutions and its impact on development," 2012.

[69] Inspectorate General, Report To Parliament. 2016.

[70] Ethics and Anti-Corruption Commission, "Report of Activities and Financial Statements for the Financial Year 2015 / 2016 for," 2016. doi: 10.1080/15216540701311147.

[71] R. Bariyo and P. T. Ngoboka, "FIGHTING CORRUPTION IN THE HEALTH SECTOR : SECURING IMPROVED HEALTHCARE SERVICE DELIVERY AND UTILIZATION IN UGANDA,” pp. $1-8$.

[72] J. C. Kohler, "Fighting corruption in the health sector methods, tools and good practices," 2011.

[73] J. Andvig, O. Fjeldstad, and A. Søreide, "Research on Corruption: A Policy Oriented Survey," Int. Aff., no. December, pp. 1-144, 2000.

[74] D. Mele, "Corruption: 10 Possible Causes | Business Ethics.”.

[75] I. Holeman, T. Cookson, and C. Pagliari, "Digital technology for health sector governance," J. Glob. Health, vol. [In print], 2016.

[76] A. Joshi, "Do They Work? Assessing the Impact of Transparency and Accountability Initiatives in Service Delivery," Dev. Policy Rev., vol. 31, pp. s29-s48, Jul. 2013, doi: 10.1111/dpr.12018.

[77] N. Kossow and V. Dykes, "Embracing Digitalisation: How to use ICT to strengthen Anti-Corruption," Giz, 2018.

[78] T. Kim, K. and Kang, "Does Technology Against Corruption Always Lead to Benefit? The Potential Risks and Challenges of the Blockchain Technology,” 2017. 
International Journal of Computer Applications (0975 - 8887)

Volume 174 - No. 20, February 2021

[79] H. Arksey and L. O. Malley, "Scoping Studies: Towards A Methodological Framework," pp. 19-32, 2005.

[80] I. Adam and M. Fazekas, "Are emerging technologies helping win the fight against corruption in developing countries?," Pathways Prosper. Comm. Backgr. Pap. Ser., vol. 21, no. April, p. 34, 2018, [Online]. Available: www.pathwayscommission.bsg.ox.ac.uk. 